\title{
Efficient Synthesis of Thiobenzanilides by Willgerodt-Kindler Reaction with Base Catalysts
}

\author{
Ken Okamoto, ${ }^{\text {a,b }}$ Takakazu Yamamoto, ${ }^{a}$ Takaki Kanbara*b,c \\ ${ }^{a}$ Chemical Resources Laboratory, Tokyo Institute of Technology, 4259 Nagatsuta, Midori-ku, Yokohama, 226-8503, Japan \\ ${ }^{b}$ Tsukuba Research Center for Interdisciplinary Materials Science (TIMS), University of Tsukuba, 1-1-1 Ten-noudai, Tsukuba 305-8573, \\ Japan \\ ${ }^{\mathrm{c}}$ Graduate School of Pure and Applied Sciences, University of Tsukuba, 1-1-1 Ten-noudai, Tsukuba 305-8573, Japan \\ Fax: +81-29-853-4490; E-mail: kanbara@ims.tsukuba.ac.jp \\ Received: The date will be inserted once the manuscript is accepted.
}

\begin{abstract}
Willgerodt-Kindler reaction between anilines and benzaldehydes readily proceeded in the presence of catalytic amount of $\mathrm{Na}_{2} \mathrm{~S} \cdot 9 \mathrm{H}_{2} \mathrm{O}$ to give thiobenzanilides in moderate to good yields. The base catalyst was also available for preparation of primary thiobenzamide.
\end{abstract}

Key words: sulfur, catalysis, condensation, aromatic amines, thioamides

Thioamides have been used in the field of medical and organic chemistry; ${ }^{1,2}$ aromatic thioamides have been notably valuable building blocks for preparation of biologically relevant five- and six-membered heterocycles. Thioamides have also attracted recent attention in inclusion chemistry, transition-metal coordination chemistry, and material chemistry. ${ }^{3}$

The Willgerodt-Kindler (WK) reaction is extensively used to synthesize various thioamides. ${ }^{1 \mathrm{f}, 4}$ However, to our knowledge, there have been only a few reports on the preparation of aromatic thioamides such as thiobenzanilide using WK reaction, ${ }^{5}$ and the yields have been low unless severe reaction conditions or microwave techniques are employed. ${ }^{6}$

Thiobenzanilide and its derivatives have generally been prepared by thionation of the corresponding benzanlides with Lawesson's reagent or $\mathrm{P}_{2} \mathrm{~S}_{5}{ }^{7}$ To dissolve the limitation of WK reaction, we have carried out the modification of the reaction conditions and found that addition of catalytic amount of base such as $\mathrm{Na}_{2} \mathrm{~S} \cdot 9 \mathrm{H}_{2} \mathrm{O}$ was efficient for the preparation of thiobenzanilides. There have been a few reports that addition of bases raised yields in WK reactions, ${ }^{8}$ however, a usability of base catalysts for synthesis of thiobenzanilides has not been examined. We here report the efficient modification of $\mathrm{WK}$ reaction for preparation of thiobenzanilides, as shown in Scheme 1. The synthetic protocol is also available for preparation of primary thiobenzamide.

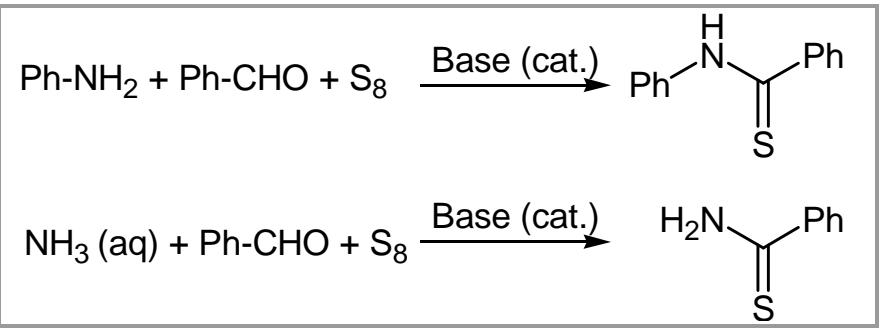

Scheme 1
The reaction of benzaldehyde with aniline and 4anisidine in the presence of sulfur under the conditions of the conventional WK reaction afforded the corresponding thiobenzanilides in low to moderate yields (15\% and 39\% yields respectively, as shown in Scheme $2)$; these results are consistent with reported literatures. $^{5 \mathrm{a}, 5 \mathrm{c}}$ The first step of WK reaction is considered to involve cleavage of the S-S bond of elemental sulfur caused by nucleophilically attack of amine to form polysulfide anions in a reversible way. ${ }^{4}$ The less basic amines such as aniline is considered to hardly lead to the formation of the polysulfide anions. In contrast, addition of a small amount $(5 \mathrm{~mol} \%)$ of $\mathrm{Na}_{2} \mathrm{~S} \cdot 9 \mathrm{H}_{2} \mathrm{O}$ in the reaction mixtures improved the reaction as shown in Scheme 2.

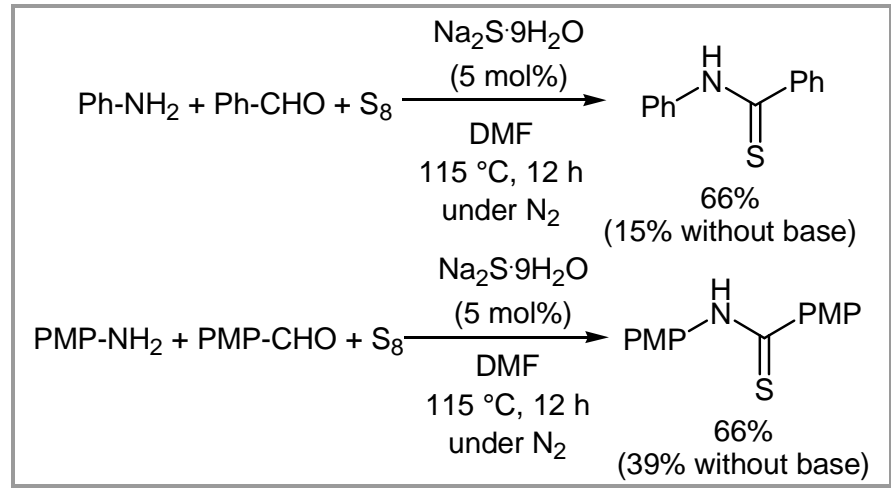

Scheme 2

To optimize the reaction conditions, WK reaction of benzaldehyde and aniline with sulfur was carried out under various conditions. As shown in Table 1, WK reaction of benzaldehyde and aniline with sulfur smoothly proceeded by the addition of $\mathrm{Na}_{2} \mathrm{~S} \cdot 9 \mathrm{H}_{2} \mathrm{O}$ as the base catalyst. The yield increased with an increase in the base content, and $91 \%$ yield is attained at $15 \mathrm{~mol} \%$ of $\mathrm{Na}_{2} \mathrm{~S} \cdot 9 \mathrm{H}_{2} \mathrm{O}$. The yield is comparable to reported yields for $\mathrm{WK}$ reaction using microwave tequnique. ${ }^{6}$ Use of other base such as $t$-BuOK, DMAP, and $\mathrm{Et}_{3} \mathrm{~N}$ gave thiobenzanilide in moderate (40-62\%) yields.

The reaction conditions of entry 9 in Table 1 have been applied for various aromatic amines and aldehydes, ${ }^{9}$ and the results are summarized in Table 2. $\mathrm{Na}_{2} \mathrm{~S} \cdot 9 \mathrm{H}_{2} \mathrm{O}$ was efficient for the preparation of several thiobenzanilides. Disubstituted aromatic thioamides, which could not be prepared by the conventional WK reaction, were ob- 
tained in moderate yields (entry 14 and 15). $\mathrm{Na}_{2} \mathrm{~S} \cdot 9 \mathrm{H}_{2} \mathrm{O}$ was also effective for the reaction of heteroaromatic amines and aldehydes (entry 17-19 and 21). New compounds (entry 17, 19, and 20) were characterized by NMR spectroscopy and elemental analysis. ${ }^{10}$

\begin{tabular}{|c|c|c|c|}
\hline Entry & Base & Time (h) & Yield $(\%)^{b}$ \\
\hline 1 & - & 12 & 15 \\
\hline 2 & $\mathrm{Et}_{3} \mathrm{~N}, 5 \mathrm{~mol} \%$ & 12 & 40 \\
\hline 3 & DMAP, $5 \mathrm{~mol} \%$ & 12 & 42 \\
\hline 4 & $t$-BuOK, $5 \mathrm{~mol} \%$ & 12 & 62 \\
\hline 5 & $\mathrm{Na}_{2} \mathrm{~S} \cdot 9 \mathrm{H}_{2} \mathrm{O}, 1 \mathrm{~mol} \%$ & 12 & 55 \\
\hline 6 & $\mathrm{Na}_{2} \mathrm{~S} \cdot 9 \mathrm{H}_{2} \mathrm{O}, 5 \mathrm{~mol} \%$ & 4 & 32 \\
\hline 7 & $\mathrm{Na}_{2} \mathrm{~S} \cdot 9 \mathrm{H}_{2} \mathrm{O}, 5 \mathrm{~mol} \%$ & 12 & 66 \\
\hline 8 & $\mathrm{Na}_{2} \mathrm{~S} \cdot 9 \mathrm{H}_{2} \mathrm{O}, 10 \mathrm{~mol} \%$ & 12 & 83 \\
\hline 9 & $\mathrm{Na}_{2} \mathrm{~S} \cdot 9 \mathrm{H}_{2} \mathrm{O}, 15 \mathrm{~mol} \%$ & 12 & 91 \\
\hline 10 & $\mathrm{Na}_{2} \mathrm{~S} \cdot 9 \mathrm{H}_{2} \mathrm{O}, 20 \mathrm{~mol} \%$ & 12 & 88 \\
\hline \multicolumn{4}{|c|}{$\begin{array}{l}{ }^{\text {a }} \text { Conditions: Reaction of aniline }(6.0 \mathrm{mmol}) \text {, benzaldehyde }(4.0 \\
\mathrm{mmol}) \text { and sulfur }(5.0 \mathrm{mmol}) \text { was performed in DMF }(4 \mathrm{~mL}) \text { at } 115 \\
{ }^{\circ} \mathrm{C} \text {. } \\
\text { b Isolated yield. }\end{array}$} \\
\hline
\end{tabular}

Scheme 3 shows a plausible role of $\mathrm{Na}_{2} \mathrm{~S} \cdot 9 \mathrm{H}_{2} \mathrm{O}$ in WK reaction. The suspension of elemental sulfur in the DMF solution of aniline remained unreacted because of the poor nucleophilicity of aniline. The addition of small amount of $\mathrm{Na}_{2} \mathrm{~S} \cdot 9 \mathrm{H}_{2} \mathrm{O}$ into the reaction mixture of sulfur with aniline caused a color change of the reaction system; from pale yellow to deep blue. Therefore, the base catalyst is considered to initiate the nucleophilic cleavage of the elemental sulfur ring to give the polysulfide anions as depicted in Scheme 3.

There have been numerous investigations concerning the reaction of elemental sulfur in amines or ammonia, ${ }^{11}$ however, the behavior and the fate of sulfur in those media have not yet been fully elucidated. From changes of the absorption spectra and conductivity of those media, Davis et al. suggested that the color change of the reaction media results from the formation of polysulfide anions and related ions generated by the initial nucleophilic attack of amines to the sulfur ring. ${ }^{11 a}$

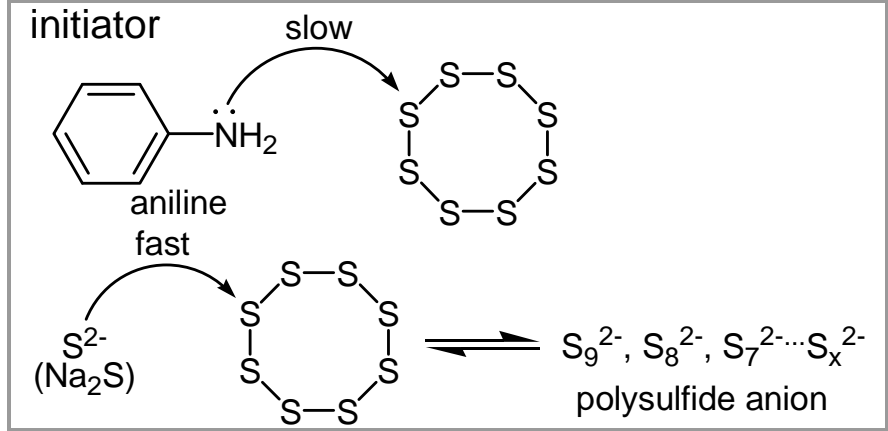

Scheme 3

$\mathrm{Na}_{2} \mathrm{~S} \cdot 9 \mathrm{H}_{2} \mathrm{O}$ was also usable for the preparation of primary thiobenzamide. In contrast to extensive study on the reaction of elemental sulfur with ammonia, ${ }^{11 \mathrm{e}}$ only a few reports concerning WK reaction of benzaldehyde with ammonia were reported; the reaction gave thiobenzamide in moderate yield under microwave irradiation. ${ }^{1 \mathrm{f}}$ The addition of the base catalyst was also effective for WK reaction of benzaldehyde with aqueous ammonia, ${ }^{12}$ and the yield was improved as shown in Scheme 4.

$$
\begin{aligned}
& \mathrm{NH}_{3}(\mathrm{aq})+\mathrm{Ph}-\mathrm{CHO}+\mathrm{S}_{8} \frac{\mathrm{Na}_{2} \mathrm{~S} \cdot 9 \mathrm{H}_{2} \mathrm{O} \text { (cat.) }}{\mathrm{DMF}} \mathrm{H}_{2} \mathrm{~N} \prod_{\mathrm{S}}^{\mathrm{Ph}} \\
& 115^{\circ} \mathrm{C}, 12 \mathrm{~h} \\
& \text { under } \mathrm{N}_{2}
\end{aligned}
$$

\section{Scheme 4}

In summary, we succeeded in improvement for the preparation of thiobenzanilides and primary thiobenzamide by WK reaction under mild conditions. The base catalyst was applicable for the preparation of various thiobenzanilides, and the results will contribute to expansion of WK reaction.

\section{Table 2 WK Reaction of Aromatic Amines, Arylaldehydes, and Sulfur with Catalytic Amount of $\mathrm{Na}_{2} \mathrm{~S} \cdot 9 \mathrm{H}_{2} \mathrm{O}^{\mathrm{a}}$}

Entry Amine

9<smiles>Nc1ccccc1</smiles>

11<smiles>COc1ccc(N)cc1</smiles>

12<smiles>Nc1ccccc1</smiles>

Aldehyde<smiles>O=Cc1ccccc1</smiles><smiles>O=Cc1ccccc1</smiles><smiles>COc1ccc(C=O)cc1</smiles>

Product<smiles>S=C(Nc1ccccc1)c1ccccc1</smiles><smiles>COc1ccc(NC(=S)c2ccccc2)cc1</smiles>

$92\left(40^{\mathrm{c}}\right)$<smiles>COc1ccc(C(=S)Nc2ccccc2)cc1</smiles> 
Table 2 WK Reaction of Aromatic Amines, Arylaldehydes, and Sulfur with Catalytic Amount of $\mathrm{Na}_{2} \mathrm{~S} \cdot 9 \mathrm{H}_{2} \mathrm{O}^{\mathrm{a}}$ (continued)

Entry

Amine

13<smiles>COc1ccc(N)cc1</smiles>

$14^{\mathrm{d}}$<smiles>Nc1ccccc1</smiles><smiles>Nc1ccccc1</smiles><smiles>O=Cc1ccc(C=O)cc1</smiles>

16<smiles>Nc1ccc([N+](=O)[O-])cc1</smiles>

17<smiles>Nc1ccncc1</smiles><smiles>Nc1cccnc1</smiles>

18

19<smiles>Nc1ccc2ncccc2c1</smiles>

$20^{\mathrm{f}}$<smiles>Nc1ccccc1</smiles>

21<smiles>Nc1ccccc1</smiles>

Aldehyde<smiles>COc1ccc(C=O)cc1</smiles><smiles>O=Cc1cccc(C=O)c1</smiles>
$\mathrm{OHC}$<smiles>O=Cc1ccccc1</smiles><smiles>O=Cc1ccccc1</smiles><smiles>O=Cc1ccccc1</smiles><smiles>N#Cc1ccc(C=O)cc1</smiles><smiles>O=Cc1ccccn1</smiles><smiles>O=Cc1ccccc1</smiles>

${ }^{\text {a }}$ Reaction was carried out in analogy with entry 9 in Table 1 .

${ }^{\mathrm{b}}$ Isolated yield; the data obtained in the absence of base is shown in parentheses.

${ }^{\mathrm{c}}$ From Ref. $5 \mathrm{c}$

d 3 equiv of aniline was used.

${ }^{\mathrm{e}}$ Not detected by TLC.

${ }^{\mathrm{f}} 5 \mathrm{~mol} \%$ of $\mathrm{Na}_{2} \mathrm{~S} \cdot 9 \mathrm{H}_{2} \mathrm{O}$ was used.

Product

Yield (\%)<smiles>C=CCOC</smiles><smiles>S=C(Nc1ccccc1)c1ccccc1</smiles><smiles>N#Cc1ccc(C(=S)Nc2ccccc2)cc1</smiles> 


\section{Acknowledgment}

The authors gratefully thank Dr. T. Koizumi of Tokyo Institute of Technology for useful discussion. The authors are grateful to the Chemical Analysis Center of University of Tsukuba, for measurements of NMR spectra and elemental analysis.

\section{References}

(1) a) Jagodziński, T. S. Chem. Rev. 2003, 103, 197. (b) Klingele, M. H.; Brooker, S. Eur. J. Org. Chem. 2004, 3422. (c) Murai, T.; Aso, H.; Tatematsu, Y.; Itoh, Y.; Niwa, H.; Kato, S. J. Org. Chem. 2003, 68, 8514. (d) Ach, D.; Reboul, V.; Metzner, P. Eur. J. Org. Chem. 2002, 2573. (e) Ares, J. J. Synth. Commun. 1991, 21, 625. (f) Zbruyev, O. I.; Stiasni, N.; Kappe, C. O. J. Comb. Chem. 2003, 5, 145. (g) Murai, T. Top. Curr. Chem. 2005, 251, 247.

(2) (a) Petrova, D.; Jakopčić, K. Croatica Chemi. Acta 1976, 48, 319 (b) Downer, N. K.; Jackson, Y. A. Org. Biomol. Chem. 2004, 2, 3039. (c) Mathis, C. A.; Wang, Y.; Holt, D. P.; Huang, G.-F.; Debnath, M. L.; Klunk, W. E. J. Med. Chem. 2003, 46, 2740.

(3) (a) Inoue, Y.; Kanbara, T.; Yamamoto, T. Tetrahedron Lett. 2003, 44, 5167. (b) Akaiwa, M.; Kanbara, T.; Fukumoto, H.; Yamamoto, T. J. Organomet. Chem. 2005, 690, 4192. (c) Okamoto, K.; Kanbara, T.; Yamamoto, T.; Wada, A. Organometallics 2006, 25, 4026. (d) Kagaya, S.; Sato, E.; Masore, I.; Hasegawa, K.; Kanbara, T. Chem. Lett. 2003, 32, 622 .

(4) (a) Kindler, K. Liebigs Ann. Chem. 1923, 431, 187. (b) Carmack, M.; Spielman, M. A. Org. React. 1946, 3, 83. (c) Brown, E. V. Synthesis 1975, 358; and references therein.

(5) (a) Bottcher, B.; Bauer, F. Liebigs Ann. Chem. 1950, 568, 218. (b) Tandel, S.; Bliznets, I.; Ebinger, K. Ma, Y.-A.; Bhumralkar, D.; Thiruvazhi, M. Tetrahedron Lett. 2004, 45, 2321. (c) Pelova, R.; Kozhukharova, A. Nauchni, Trudove Plovdivski Universitet Paisii Khilendarski 1982, 20 (3, Khim), 79

(6) Bulavka, V. N. 8th Electron. Conf. Synth. Org. Chem. (ECSOC-8), 2004, E008.

(7) (a) Varma, R. S.; Kumar, D. Org. Lett. 1999, 1, 697. (b) Curphey, T. J. J. Org. Chem. 2002, 67, 6461.

(8) (a) Poupaert, J. H.; Bouinidane, K.; Renard, M.; Lambert, D. M.; Isa, M. Org. Prep. Proced. Int. 2001, 33, 335. (b) Moghaddam, F. M.; Boinee, H. Z.; Taheri, S. J. Sulfur Chem. 2004, 25, 407.

(9) Experimental Procedure (Table 1, entry 9). $\mathrm{Na}_{2} \mathrm{~S} \cdot 9 \mathrm{H}_{2} \mathrm{O}(216 \mathrm{mg}, 15 \mathrm{~mol} \%)$ was added to a mixture of sulfur (160 mg, $5 \mathrm{mmol}$ as elemental sulfur) and aniline $(0.55 \mathrm{~mL}, 6 \mathrm{mmol})$ in DMF $(4 \mathrm{~mL})$, and the suspension was stirred at $115^{\circ} \mathrm{C}$ for $0.5 \mathrm{~h}$ under nitrogen. After the mixture was cooled to r.t., benzaldehyde $(0.41 \mathrm{~mL}, 4$ mmol) was added, and was stirred at $115^{\circ} \mathrm{C}$ for $12 \mathrm{~h}$ under nitrogen. After cooling to r.t., the resulting solution was quenched with sat. aq $\mathrm{NH}_{4} \mathrm{Cl}$ solution $(50 \mathrm{~mL})$ and extracted with $\mathrm{CHCl}_{3}(50 \mathrm{~mL})$. The organic fraction was thoroughly washed with water $(2 \times 50 \mathrm{~mL})$ and dried with anhydrous sodium sulfate. After concentration, the resulting crude product was purified by chromatography on silica gel with $\mathrm{CHCl}_{3}$ to afford $\mathrm{N}$-phenylthiobenzamide as a yellow powder $\left(560 \mathrm{mg}, 91 \%\right.$ yield): $\mathrm{mp} 99^{\circ} \mathrm{C}$, lit. $^{7} 99^{\circ} \mathrm{C}$.

(10) $\quad \boldsymbol{N}$-(4-Methoxyphenyl)thiobenzamide (Table 2, entry 11) Yellow powder, mp $135^{\circ} \mathrm{C}$, lit. $^{7} 135^{\circ} \mathrm{C}$.

4-Methoxy- $N$-phenylthiobenzamide (Table 2, entry 12) Yellow powder, mp $154{ }^{\circ} \mathrm{C}$, lit. ${ }^{7} 153-154^{\circ} \mathrm{C}$.

4-Methoxy- $\boldsymbol{N}$-(4-methoxyphenyl)thiobenzamide (Table 2, entry 13) Yellow powder, mp $148{ }^{\circ} \mathrm{C}$, lit. $^{7} 148^{\circ} \mathrm{C}$.

1,3-Bis(anilinothiocarbonyl)benzene (Table 2, entry 14) Yellow powder, mp $243-244^{\circ} \mathrm{C}$, lit. ${ }^{2 \mathrm{a}} 242-244{ }^{\circ} \mathrm{C}$.
1,4-Bis(anilinothiocarbonyl)benzene (Table 2, entry 15) Yellow powder, mp $280-281{ }^{\circ} \mathrm{C}$, lit. ${ }^{2 \mathrm{a}} 280-282^{\circ} \mathrm{C}$.

$\mathrm{N}$-(4-Nitrophenyl)-thiobenzamide (Table 2, entry 16) Yellow powder, mp $145-146^{\circ} \mathrm{C}$, lit. $^{13} 145^{\circ} \mathrm{C}$.

$N$-(4-Pyridyl)thiobenzamide (Table 2, entry 17) Yellow powder, mp $187-188^{\circ} \mathrm{C} .{ }^{1} \mathrm{H}$ NMR (DMSO- $d_{6}, 400 \mathrm{MHz}$ ): $\delta=11.99(\mathrm{~s}, 1 \mathrm{H}), 9.59(\mathrm{~d}, 2 \mathrm{H}, J=6.4 \mathrm{~Hz}), 8.00(\mathrm{~d}, 2 \mathrm{H}, J=$ $6.4 \mathrm{~Hz}), 7.78(\mathrm{~d}, 2 \mathrm{H}, J=7.6 \mathrm{~Hz}), 7.55(\mathrm{t}, 1 \mathrm{H}, J=7.6 \mathrm{~Hz})$, $7.47(\mathrm{t}, 2 \mathrm{H}, J=7.6 \mathrm{~Hz}) .{ }^{13} \mathrm{C}\left\{{ }^{1} \mathrm{H}\right\}$ NMR (DMSO-d 6,100 MHz): $\delta=199.35,150.17,146.64,142.78,130.99,128.00$, 127.37, 116.67. Anal. Calcd for $\mathrm{C}_{12} \mathrm{H}_{10} \mathrm{~N}_{2} \mathrm{~S}: \mathrm{C}, 67.26 ; \mathrm{H}$, 4.70; N, 13.07; S, 14.96. Found: C, 67.32; H, 4.52; N, $13.15 ; \mathrm{S}, 14.88$.

$N$-(3-Pyridyl)thiobenzamide (Table 2, entry 18) Yellow powder, mp $140-141^{\circ} \mathrm{C}$, lit. ${ }^{14} 140-141^{\circ} \mathrm{C}$.

$N$-(6-Quinolyl)thiobenzamide (Table 2, entry 19) Orange powder, mp $177-179^{\circ} \mathrm{C} .{ }^{1} \mathrm{H}$ NMR (DMSO- $d_{6}, 400 \mathrm{MHz}$ ): $\delta=12.03(\mathrm{~s}, 1 \mathrm{H}), 8.90(\mathrm{br}, 1 \mathrm{H}), 8.56(\mathrm{br}, 1 \mathrm{H}), 8.38(\mathrm{~d}, 1 \mathrm{H}$, $J=8.0 \mathrm{~Hz}), 8.11-8.05(\mathrm{~m}, 2 \mathrm{H}), 7.89(\mathrm{~d}, 2 \mathrm{H}, J=7.6 \mathrm{~Hz})$, 7.56-7.53 (m, 2H), $7.49(\mathrm{t}, 2 \mathrm{H}, J=7.6 \mathrm{~Hz}) .{ }^{13} \mathrm{C}\left\{{ }^{1} \mathrm{H}\right\} \mathrm{NMR}$ (DMSO- $d_{6}, 100 \mathrm{MHz}$ ): $\delta=199.81,151.99,147.55,144.08$, $139.55,137.49,132.50,130.65,129.67,129.29,129.08$, 128.86, 123.41, 123.00. Anal. Calcd for $\mathrm{C}_{16} \mathrm{H}_{12} \mathrm{~N}_{2} \mathrm{~S}: \mathrm{C}$, 72.70; H, 4.58; N, 10.60; S, 12.13. Found: C, 72.62; H, $4.51 ; \mathrm{N}, 10.60 ; \mathrm{S}, 11.97$.

4-Cyano- $\boldsymbol{N}$-phenylthiobenzamide (Table 2 , entry 20 ) Orange powder, $\mathrm{mp} 130-131{ }^{\circ} \mathrm{C}$. ${ }^{1} \mathrm{H}$ NMR (DMSO-d $d_{6}, 400$ MHz): $\delta=12.01(\mathrm{~s}, 1 \mathrm{H}), 7.93-7.91(\mathrm{br}, 4 \mathrm{H}), 7.83(\mathrm{~d}, 2 \mathrm{H}, J$ $=8.0 \mathrm{~Hz}), 7.44(\mathrm{t}, 2 \mathrm{H}, J=8.0 \mathrm{~Hz}), 7.29(\mathrm{t}, 1 \mathrm{H}, J=8.0 \mathrm{~Hz})$. ${ }^{13} \mathrm{C}\left\{{ }^{1} \mathrm{H}\right\}$ NMR (DMSO- $\left.d_{6}, 100 \mathrm{MHz}\right): \delta=195.16,146.14$, 139.47, 131.96, 128.42, 127.95, 126.42, 123.74, 118.27, 112.54. Anal. Calcd for $\mathrm{C}_{14} \mathrm{H}_{10} \mathrm{~N}_{2} \mathrm{~S}: \mathrm{C}, 70.56 ; \mathrm{H}, 4.23 ; \mathrm{N}$, 11.76. Found: C, 70.85; H, 4.45; N, 11.71 .

$\mathrm{N}$-Phenyl-2-pyridinethioamide (Table 2 , entry 21 ) Orange Yellow powder, $\mathrm{mp} 45^{\circ} \mathrm{C}$, lit. ${ }^{15} 45^{\circ} \mathrm{C}$

(11) (a) Davis, R. E.; Nakshbendi, H. F. J. Am. Chem. Soc. 1962, 84, 2085. (b) McMillan, F. H.; King, J. A. J. Am. Chem. Soc. 1948, 70, 4143. (c) B. D. Vineyard J. Org. Chem. 1967, 32, 3833. (d) R. MacColl; S. Windwer J. Phys. Chem. 1970, 74, 1261. (e) Sato, R.; Sato, T.; Segawa, K.; Takikawa, Y.; Takizawa, S.; Oae, S. Phosphorus Sulfur Silicon Relat. Elem. 1979, 7, 213.

(12) Thiobenzamide (Scheme 4)

$\mathrm{Na}_{2} \mathrm{~S} \cdot 9 \mathrm{H}_{2} \mathrm{O}(244 \mathrm{mg}, 1 \mathrm{mmol})$ was added to a mixture of sulfur (160 mg, $5 \mathrm{mmol}$ as elemental sulfur) and $28 \%$ aq ammonia (3 $\mathrm{mL}$, ca. $44 \mathrm{mmol})$ in DMF $(4 \mathrm{~mL})$, and the suspension was stirred at $115^{\circ} \mathrm{C}$ for $0.5 \mathrm{~h}$ under nitrogen. After the mixture was cooled to r.t., benzaldehyde $(0.41$ $\mathrm{mL}, 4 \mathrm{mmol}$ ) was added, and stirred at $115^{\circ} \mathrm{C}$ for $12 \mathrm{~h}$ under nitrogen. After cooling to r.t., the resulting solution was quenched with sat. aq $\mathrm{NH}_{4} \mathrm{Cl}$ solution $(50 \mathrm{~mL})$ and extracted with $\mathrm{CHCl}_{3}(50 \mathrm{~mL})$. The organic fraction was thoroughly washed with water $(2 \times 50 \mathrm{~mL})$ and dried with anhydrous sodium sulfate. After concentration, the resulting crude material was purified by chromatography on silica gel with $\mathrm{CHCl}_{3}-\mathrm{Et}_{2} \mathrm{O}$ (100:0 to 20:80) to afford thiobenzamide as a pale yellow powder ( $270 \mathrm{mg}, 49 \%$ yield $): \mathrm{mp}$ $118^{\circ} \mathrm{C}$, lit. $^{7 \mathrm{~b}} 117-118^{\circ} \mathrm{C}$.

(13) Reynaud, P.; Moreau, R. C.; Samama, J. P. Bull. Soc. Chim. Fr. 1965, 12, 3623.

(14) Couture, A.; Grandclaudon, P. Synthesis, 1985, 5, 533.

(15) Mazumder, U. K.; Gupta, M.; Karki, S. S.; Bhattacharya, S.; Rathinasamy, S.; Sivakumar, T. Bioorg. Med. Chem. 2005, 13, 5766. 
Please place the graphical abstract and short title of the article here. The short title will be used as a running header.<smiles>NC(=S)c1ccccc1-c1cccc(NC(=S)c2ccccc2)c1</smiles>

Base Assisted Willgerodt-Kinder Reaction

\section{Manuscript submission checklist}

- Statement of significance of work.

- Full mailing address, telephone and fax numbers, and email address of the corresponding author.

- Paper save as a PDF file.

- Original Word file.

- Original graphic files.

- Graphical abstract. 